DOI 10.4467/2543733XSSB.17.024.8322

\title{
ROBERT KŁACZYŃSKI
}

Instytut Politologii

Uniwersytet Pedagogiczny im. KEN w Krakowie

\section{POLITYKA IMPERIUM ROSYJSKIEGO WOBEC PAŃSTW, NARODÓW BAŁKAŃSKICH 1826-1914}

\begin{abstract}
Słowa kluczowe: Imperium Rosyjskie, państwa bałkańskie, ekspansja militarna, ekspansja polityczna
\end{abstract}

\section{Wprowadzenie}

Bałkany to region o strategicznym znaczeniu dla rozwoju stosunków międzynarodowych na Starym Kontynencie. Usytuowanie Półwyspu Bałkańskiego sprawia, iż kontrola nad nim daje możliwość skutecznego politycznego, militarnego, w końcu gospodarczego oddziaływania na procesy zachodzące zarówno w południowej, jak również środkowej Europie. Postępująca globalizacja spłaszcza znaczenie przestrzeni, pozwala tym samym na pewne przeformułowanie położenia geopolitycznego Bałkanów. Nie oznacza to jednak, iż w czasach nam współczesnych region ten nadal nie należy do kluczowych dla rozwoju sytuacji na Starym Kontynencie. Historia podboju narodów bałkańskich sięga czasów starożytnych, gdy tereny te były areną kolejnych prób kolonizacji, podejmowanych przez legiony rzymskie ${ }^{1}$. W schyłkowym okresie średniowiecza przyszedł czas na ekspansję Imperium Osmańskiego, którego celem było zdobycie stolicy cesarstwa bizantyjskiego Konstantynopola, a następnie podbój pozostałej części Półwyspu Bałkańskiego². Bałkany stały się wówczas areną rywalizacji Habsburgów z Osmanami, trwającej, poczynając od XV wieku, z przerwami aż do I wojny światowej. Przez pewien czas Bałkany znalazły się w kręgu zainteresowań polskiej dynastii Jagiellonów. Klęska pod Warną w 1444 roku, wybranie za sprawą Litwy ekspansji na kierunku wschodnim oraz śmierć Ludwika Jagiellończyka w bitwie pod Mohaczem w 1526 roku de facto zakończyły bezpośredni udział

${ }^{1}$ Szerzej J. Wo 1 s k i, Historia powszechna. Starożytnośćc, Warszawa 1971, s. 72, 149, 152, 258, 282, 406, 408, 422, 427, 448, 502, 408.

${ }^{2}$ P. W ró be 1, Krzyż i Pótksiężyc. Zachodnie Batkany wobec Turcji w latach 1444-1463, Warszawa 2012.

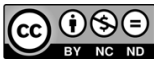


Polski w grze o Bałkany. Jednak należy przy tym przypomnieć, iż to polski władca Jan III Sobieski skutecznie dopomógł Habsburgom w podjęciu działań na rzecz przywrócenia ich władzy nad Bałkanami, pokonując wojska tureckie pod Wiedniem w 1683 roku³.

W wyniku reform podjętych na przełomie XVII/XVIII stulecia coraz większą rolę na arenie międzynarodowej zaczęła odgrywać Rosja. Realizację strategicznych zadań politycznych rodzącego się imperium napędzały idee mesjanistyczne, według których Rosja miała stać się centrum jednoczącym pod berłem dynastii Romanowów wszystkich Słowian, uciskanych zarówno przez Turcję, jak również żywioł niemiecki. Romanowowie uważali się za spadkobierców tradycji cesarstwa bizantyjskiego. Bizantynizm jako idea znalazł szerokie poparcie wśród rosyjskich elit politycznych. Stąd też obok prozaicznej gry interesów wzięło się tak mocne zaangażowanie strony rosyjskiej w konflikty na Bałkanach $^{4}$. Istotne dla rozwoju sytuacji na wspomnianym obszarze było to, że ze względu na zaangażowanie tam Imperium Rosyjskiego, rosyjskie elity władzy uznały się za obrońców religii prawosławnej, tym samym stając się orędownikami narodów bałkańskich, dla części których prawosławie stanowiło główny fundament podtrzymujący tendencje niepodległościowe, poczucie tożsamości narodowej, miejscową kulturę. W taki sposób narodziła się kolejna idea, która przez blisko dwa stulecia napędzała rosyjską politykę zagraniczną na kierunku europejskim - panslawizm5 Z Zaangażowanie Rosji na Bałkanach w XIX wieku oraz w pierwszej dekadzie wieku XX niewątpliwie przyczyniło się do odzyskania niepodległości przez narody bałkańskie i wyparcia Imperium Osmańskiego

${ }^{3}$ Klęska pod Warną była wynikiem braku odpowiedniej wiedzy ze strony polskich elit politycznych, obejmującej szeroko rozumianą ,politykę bałkańską”. Chęć dorównania najważniejszym monarchiom europejskim przysłoniła ograniczone możliwości militarne, polityczne państwa polskiego oraz brak rozeznania rosnących możliwości Imperium Osmańskiego. Kreujący polską politykę zagraniczną po śmierci Władysława Jagiełły Zbigniew Oleśnicki za przyczynę klęski podawał również brak odpowiedniego zaangażowania po stronie polskiej słabnącego cesarstwa bizantyjskiego, państwa papieskiego oraz niejednoznaczną postawę Wenecji. Należałoby jeszcze dodać do tego wewnętrzne spory w ramach kierownictwa państwa polskiego, do których należy zaliczyć konflikt na linii Zbigniew Oleśnicki - Władysław III. T. G r a ff, Wizja polityczna Zbigniewa Oleśnickiego po śmierci Władysława III, Prace Komisji Środkowoeuropejskiej PAU, J. Machnik, I. Stawowy-Kawka (red.), t. XXII, Kraków 2014, s. 21-44.

Wiktoria wiedeńska przyczyniła się również do wzrostu znaczenia Rosji, Wenecji w politycznej rozgrywce o Bałkany. Polska, nie licząc zażegnania niebezpieczeństwa w postaci grożącej interwencji ze strony Imperium Osmańskiego, uzyskała mocno ograniczone profity polityczne i terytorialne (odzyskanie Podola wraz z Kamieńcem Podolskim w 1699 roku). L. P o d h or e c k i, Wiedeń 1683, Warszawa 1983, s. 190-206; W. K o n o p c zy ńs k i, Polska a Turcja 1683-1792, Kraków-Warszawa 2013, s. 7-32.

Klęska poniesiona przez Osmanów w bitwie pod Wiedniem stała się początkiem końca ich panowania nad Bałkanami, przyczyniła się również do pogłębienia sporu o Bałkany pomiędzy decydującymi o losach Europy monarchiami: „Rozpoczęta za Sulejmana Wspaniałego polityka czynnej ingerencji i udziału Imperium Osmańskiego w koncercie europejskim została tym samym zakończona, z podmiotu stało się ono przedmiotem polityki europejskiej. Rozpoczęła się odtąd z jednej strony gra państw europejskich o spadek po Turcji, a z drugiej rozpaczliwe próby Turcji utrzymania dotychczasowych posiadłości i pozycji”. Cyt. za J. R e y c h m a n, Historia Turcji, Wrocław-Warszawa-Kraków-Gdańsk 1973, s. 111.

${ }^{4}$ Rosjanie uznają, iż: „Rosja jest córką Bizancjum”, zaś „kultura rosyjska wywodzi się z kultury bizantyjsko-prawosławnej". N. F i e d o row, Docz Bizantii, [w:] A. N. Zamiatina (red.), Imperija prostranstwa. Chrestomatia, Moskwa 2003, s. 27; H. Kow a ls k a, Kultura bizantyjsko-prawosławna, [w:] L. Suchanek (red.), Rosjoznawstwo, Kraków 2004.

${ }_{5}$ Szerzej T. Ste faniuk, Danilewski panslawizm i wielość cywilizacji, Lublin 2006; P. Eberhardt, Rosyjski panslawizm jako idea geopolityczna, http://jozefdarski.pl/uploads/zalacznik/7134/geopolitykanet-rosy jskipanslawizmjakoideageopolityczna.pdf (11.11.16). 
z obszaru Półwyspu Bałkańskiego. Niemniej spowodowało również narastanie konfliktów w samej Europie, czego wynikiem była wojna krymska w latach 1853-1856 oraz I wojna światowa.

Największy udział Imperium Rosyjskiego w polityce wobec Bałkanów przypada na lata 1826-1914 i to on będzie przedmiotem moich rozważań w niniejszej publikacji. Na temat poszczególnych etapów konfliktów, ogniskujących się bezpośrednio na obszarze Bałkanów lub wokół regionu, napisano szereg monografii. Kwestia Bałkanów jest również częścią każdej niemalże książki traktującej o historii imperium Romanowów. Analizę politycznych i historycznych rozważań dotyczących Bałkanów postanowiłem oprzeć na metodzie studium przypadku, najlepiej moim zdaniem nadającej się do relatywnie krótkich ram artykułu.

\section{Polityka Imperium Rosyjskiego wobec Bałkanów w latach 1826-1853. Uwarunkowania międzynarodowe}

Początek wieku XIX w Europie to powrót do klasycyzmu, ponowne odkrywanie bogatej kultury śródziemnomorskiej, co przełożyło się na wzrost sympatii prohelleńskich, owocujących powstaniem licznych formalnych i nieformalnych stowarzyszeń „,filohelleńskich". Odżyły wówczas plany ostatecznego wyparcia Osmanów z Półwyspu Bałkańskiego. Na Bałkany zaczęli przybywać ochotnicy, emisariusze wolności, pragnący wyrwać starożytną Grecję z rąk Imperium Osmańskiego; były wśród nich postacie reprezentujące europejskie elity społeczno-kulturowe, jak choćby legendarny lord Byron, którego śmierć w wojnie o niepodległość Grecji nadała nadzwyczajny rozgłos „sprawie bałkańskiej”, czyniąc ją kluczową w polityce wielkich monarchii Starego Kontynentu' ${ }^{6}$ Obrazy wielkich mistrzów, takie jak Rzeź na Chios Eugene’a Delacroix, przedstawiające gehennę ludności cywilnej pod rządami Osmanów ogniskowały uwagę opinii publicznej, która zachęcała elity polityczne do bardziej zdecydowanych niż dotąd działań wymierzonych w panowanie osmańskie na Bałkanach ${ }^{7}$. Zapewne miało to również przełożenie na politykę rosyjską wobec Bałkanów, choć należy stwierdzić, iż zainteresowanie tym obszarem ze strony dynastii Romanowów miało znacznie głębsze przyczyny. Już w czasach panowania Katarzyny II Rosjanie zaczęli snuć projekty zdobycia Konstantynopola (Stambułu), który jako „Nowe Bizancjum” miał stanowić swoistą pieczęć do legitymizacji potęgi imperium Romanowów ${ }^{8}$. W wyniku wywieranej w pierwszym ćwierćwieczu XIX stulecia presji rosyjskiej wobec Imperium Osmańskiego, to ostatnie zmuszone było w 1826 roku przyznać Serbii, Mołdawii, Wołoszczyźnie autonomię. Rosyjsko-tureckie porozumienie zostało niechętnie przyjęte przez inne wielkie europejskie mocarstwa, obawiające się nadmiernego wzrostu potęgi imperium Romanowów. Szczególnie mocno na rewizję rosyjsko-tureckie-

\footnotetext{
${ }^{6}$ A. M. Brzezińs ki, Grecja, Warszawa 2002, s. 23-24.

${ }^{7}$ M. J. Willa u m e, Bałkany w XIX stuleciu, [w:] M. P o dola k, Wprowadzenie do studiów wschodnioeuropejskich. Bałkany: przeszłość, teraźniejszość, przyszłość, Lublin 2013, s. 17.

${ }^{8}$ Po zwycięskim dla Rosjan szturmie Oczkowa w 1788 roku, caryca Katarzyna II kazała udekorować marmurową bramę w Carskim Siole słowami skierowanymi do zwycięskiego Potiomkina: „Wkroczysz wśród braw do soboru Zofii". Stanowiło to zapowiedź zdobycia Konstantynopola (Stambułu) i realizacji idei wskrzeszenia imperium wschodniego. S. S. M o n te fi or e, Potiomkin. Ksiązę książąt, Warszawa 2000, s. 487.
} 
go układu naciskała Wielka Brytania, która wysłała do Rosji w celu politycznych negocjacji lorda Wellingtona, co niewątpliwie świadczyło o znaczeniu Bałkanów w polityce międzynarodowej. Wynikiem rosyjsko-brytyjskich rozmów było porozumienie, na mocy którego Grecja miała otrzymać szeroką autonomię, zaś interesy i wpływy tureckie w tym kraju ulec dalszemu osłabieniu. Należało jednak skłonić Osmanów do podporządkowania się europejskiemu projektowi stabilizacji sytuacji politycznej na Półwyspie Bałkańskim. Niemniej Turcy postanowili stawić desperacki opór. W latach 1826-1829 Rosja, Wielka Brytania oraz Francja wspólnie kontynuowały działania bojowe wymierzone w panowanie osmańskie na Półwyspie Bałkańskim. Jesienią 1827 roku doszło do wielkiej bitwy morskiej pod Navarino, w której turecka marynarka wojenna poniosła klęskę ${ }^{9}$ W lutym 1830 roku w Londynie nastąpiło ostateczne formalne uznanie niepodległości Grecji, choć nie wszystkie obszary ją tworzące zostały włączone w skład niepodległego państwa. Część z nich w dalszym ciągu pozostawała pod jurysdykcją Osmanów, co wynikało z chęci osłabienia rosyjskich wpływów na Bałkanach przez rywalizującą z imperium Romanowów o pozycję światowego hegemona Wielką Brytanię. Niewątpliwym sukcesem strony rosyjskiej było uzyskanie możliwości swobodnej żeglugi poprzez Bosfor i Dardanele oraz wolności handlu na obszarze Imperium Osmańskiego. Rosja przyjęła również na siebie rolę gwaranta Mołdawii i Wołoszczyzny ${ }^{10}$. Konferencja londyńska przyniosła rozczarowanie liczącym na niepodległość narodom bałkańskim, zaś brak skutecznych rozwiązań podstawowych problemów stanowił preludium do nowych wojen na wspomnianym obszarze. Wyraźnie też uwidoczniły się różnice pomiędzy wielkimi mocarstwami, które Bałkany traktowały instrumentalnie, jako narzędzie kreacji politycznej rzeczywistości w świecie, gdzie nadal obowiązywały zasady Świętego Przymierza, przyjętego w wyniku obrad wielkich mocarstw w czasie wieńczącego epokę napoleońską kongresu wiedeńskiego ${ }^{11}$.

Scenariusz polegający na kolejnych triumfach armii rosyjskiej nad siłami Imperium Osmańskiego, a następnie osłabianiu znaczenia tych zwycięstw przez mocarstwa zachodnie, stał się dominujący aż do wybuchu I wojny światowej. W obawie przed wzrostem znaczenia Rosji na arenie międzynarodowej, mocarstwa zachodnie starały się ograniczać znaczenie jej zwycięstw nad słabnącymi Osmanami. Wskutek tak definiowanej polityki Osmanom udało się niemalże do rozpoczęcia I wojny światowej utrzymać na Półwyspie Bałkańskim, choć rola, którą tam odgrywali, wyraźnie osłabła. Byli oni raczej narzędziem w rękach zachodniej dyplomacji niż kreatorem wydarzeń:

Zaangażowane na szerszej arenie Rosja i Wielka Brytania przez cały wiek XIX rywalizowały ze sobą o ziemie i wpływy na rozległym pasie terytoriów, traktując państwo osmańskie jako skuteczną barierę dla rosyjskiej ekspansji na Bliskim Wschodzie, rząd brytyjski najczęściej dążył do zachowania jego integralności terytorialnej. Podobne poglądy wyznawano w monarchii habsburskiej. W przeciwieństwie do nich, zarówno Rosja jak i Francja, przynajmniej w niektórych konfliktach, większą przychylnością darzyły ruchy narodowe. Zagadnienia przyszłości ziem osmańskich, określane w dyplomacji epoki jako kwestia wschodnia, było prawdopodobnie głównym zarzewiem międzynarodowych nieporozumień w latach 1815-1914 ${ }^{12}$.

\footnotetext{
9 P. Wi e c zork i ew i c z, Historia wojen morskich. Wiek pary, Poznań 2015, s. 23-32.

${ }^{10}$ L. B a zy low, Historia Rosji, Warszawa 1983, s. 213.

11 Ibidem, s. 204-212; A. M. B r zeziń s k i, Grecja, Warszawa 2002, s. 25-26.

12 Cyt. za B. Jela vi c h, Historia Bałkanów. Wiek XX, Kraków 2005, s. 15.
} 


\section{Koniec Świętego Przymierza. Wojna krymska 1853-1856}

Jednym z efektów zaangażowania imperium Romanowów na Bałkanach była wojna krymska. Koalicja państwa zachodnich z Wielką Brytanią, Francją, Królestwem Sardynii, wspieranymi przez Imperium Osmańskie, w wyniku krwawych walk toczonych głównie na Półwyspie Krymskim pokonała wojska rosyjskie. Wojna krymska przyniosła ze sobą kres Świętego Przymierza, a co za tym idzie utrzymującego się od czasu upadku Napoleona Bonaparte społeczno-politycznego porządku. Na blisko dwie dekady osłabiła siłę oraz znaczenie Rosji na arenie międzynarodowej; zahamowała również jej ekspansję na Bałkany. Była też pierwszym sygnałem załamywania się systemu rządów sprawowanych przez dynastię Romanowów. Rosja musiała zarzucić śmiałą koncepcję zdobycia Konstantynopola (Stambułu), zdominowania Półwyspu Bałkańskiego, w końcu narzucenia swojego zwierzchnictwa nad prawosławnymi w większości narodami zamieszkującymi obszar Bałkanów. Ponadto wojna nie przyniosła wiążącego rozwiązania rozpoczętego w 1852 roku rosyjsko-francuskiego sporu o prawa duchowieństwa prawosławnego, względnie katolickiego, do opieki nad ludnością Bałkanów oraz miejscami świętymi zajmowanymi przez Osmanów. W przededniu zakończenia działań bojowych na Półwyspie Krymskim strony zwycięskie, a więc Wielka Brytania i Francja, oraz neutralna do tej pory Austria, weszły w spór dotyczący warunków przyszłego pokoju z Rosją. Wielka Brytania dążyła do osłabienia imperium Romanowów, licząc na uzyskanie pełnego pola manewru w polityce zagranicznej, w tym w szczególności w ramach „Wielkiej Gry” toczonej z Rosją o supremację w regionie Azji Centralnej. Francja zaś, obawiając się nadmiernego wzrostu potęgi brytyjskiej, dążyła do minimalizacji strat politycznych, a także terytorialnych poniesionych w wyniku konfliktu krymskiego przez stronę rosyjską. Swoją pozycję kosztem przegranej Rosji chciała umocnić Austria, która bezpośrednio rywalizowała z imperium Romanowów o wpływy na Bałkanach. Franciszek Józef II liczył, iż przegrana wojna krymska zepchnie na margines bałkańskiej polityki Rosję, czyniąc beneficjentem wydarzeń cesarstwo austriackie. Tak się jednak nie stało. Do historii dyplomacji przeszły słowa, które wypowiedział hrabia Orłow do ministra spraw zagranicznych Francji, hrabiego Walewskiego: „Skakaliśmy sobie do gardła, jak przystało na uczciwe rasowe buldogi. Teraz wspólnymi siłami musimy postarać się, aby ta kundlowata Austria nic na naszej bójce nie skorzystała"13. W tak definiowanej rzeczywistości kwestia państw bałkańskich musiała zejść na dalszy plan. Stanowiły one wygodną kartę przetargową w prowadzonej przez wielkie mocarstwa polityce zagranicznej, rodzaj narzędzia kreacji politycznej rzeczywistości. Interesy miejscowych narodów, ich aspiracje niepodległościowe liczyły się znacznie mniej. Utrzymane zostało zwierzchnictwo Imperium Osmańskiego nad Serbią, wyrastającą na najbardziej prorosyjskie państwo regionu. Mimo uczestnictwa w koalicji antyrosyjskiej sukcesami nie mogło się pochwalić Imperium Osmańskie, którego marginalizacja zarówno w wymiarze politycznym, jak również militarnym postępowała. W wyniku zawartego pomiędzy wielkimi mocarstwami porozumienia pokojowego, wynegocjowanego w Paryżu w 1856 roku, ograniczone zostały możliwości działania przez Imperium Rosyjskie na akwenie czarnomorskim. Morze Czarne, uznawane przez Rosjan za wyłączną strefę wpływów, zostało ogłoszone akwenem neutralnym i odtąd nie mogły

${ }^{13}$ Cyt. za A. Li e b feld, Napoleon III, Warszawa 1979, s. 200. 
już po nim swobodnie operować zarówno rosyjskie, jak i tureckie eskadry okrętów wojennych. Natomiast dostęp do niego uzyskały statki handlowe należące do wszystkich państw europejskich ${ }^{14}$. Rosja oraz Turcja podjęły zobowiązanie niewznoszenia nowych fortyfikacji, instalacji wojskowych na wybrzeżu Morza Czarnego. Rosjanom pozwolono wprawdzie odzyskać władzę na Krymem, ale musieli zrezygnować z Południowej Besarabii na rzecz Mołdawii. Choć Imperium Osmańskie utrzymało zwierzchnictwo nad Mołdawią, Serbią, Wołoszczyzną, to wszystkie te państwa miały zagwarantowaną przez zwycięskie mocarstwa autonomię. Jedynie na obszarze Serbii mogły stacjonować garnizony tureckie. W granice Imperium Osmańskiego wrócił też Kars ${ }^{15}$. Polityczne wsparcie uzyskał sojusznik wielkich mocarstw w wojnie krymskiej Królestwo Sardynii, ale do zjednoczenia Włoch było jeszcze daleko. Konsekwencje wojny krymskiej okazały się dużo poważniejsze, niż wówczas przypuszczano. Definiowana początkowo jako konflikt regionalny konfrontacja wielkich mocarstw doprowadziła do trwałych zmian na arenie międzynarodowej. Nierozwiązana kwestia przyszłości narodów, państw bałkańskich szybko miała wrócić na arenę międzynarodową, stając się z czasem zarzewiem nowych wojen i konfliktów. Ekspansja imperium Romanowów została powstrzymana na dwie dekady, nie wpłynęła jednak znacząco na zmianę strategii rosyjskiej polityki zagranicznej. Rosjanie stali się bardziej zachowawczy, ostrożniejsi w podejmowaniu decyzji, nie rezygnując jednak ze swoich bałkańskich priorytetów ${ }^{16}$. Kongres paryski przyniósł narodom bałkańskim jeszcze jedną ważną informację - mianowicie, że rola i pozycja Habsburgów w polityce międzynarodowej wyraźnie słabnie ${ }^{17}$. Sytuację tę wykorzystały pretendujące do roli mocarstwa Prusy.

\section{Imperium Rosyjskie wobec państw, narodów bałkańskich: 1856-1877}

W wyniku porażki poniesionej w wojnie krymskiej polityka zagraniczna realizowana przez Imperium Rosyjskie znalazła się w wyraźnym impasie:

Klęska poniesiona przez Rosję w Wojnie Krymskiej poważnie utrudniała prowadzenie aktywnej polityki zagranicznej, zwłaszcza gdy chodziło o sprawę cieśnin czy też w ogóle o zagadnienia czarnomorskie i bałkańskie. Znacznego uszczerbku doznał prestiż międzynarodowy Rosji, która musiała się podporządkować warunkom traktatu paryskiego. W takiej sytuacji tylko zniesienie postanowień o restrykcjach na Morzu Czarnym mogło wprowadzić rosyjską politykę zagraniczną na inne tory ${ }^{18}$.

Jedynym wyjściem z sytuacji było podjęcie działań mających na celu rewizję niekorzystnych dla Rosji porozumień paryskich. Klęska w wojnie krymskiej miała również niekorzystny wpływ na sytuację wewnętrzną państwa. Rosjanom pozostało zatem usta-

${ }_{14}$ M. Klime cki, Krym 1854-1855, Warszawa 2006, s. 253.

${ }^{15}$ M. Chwastowa, W. S. S mirnowa, S. D. Skazkina, W. A. Zorina (red.), Historia dyplomacji do 1871 roku, t. 1, Warszawa 1973, s. 675.

${ }^{16}$ M. Helle r, Historia Imperium Rosyjskiego, Warszawa 2002, s. 579-583; zob. o wojnie krymskiej J. Tarle, Wojna krymska, t. 1-2, Warszawa 1953.

${ }^{17}$ H. K is s in ge r, Dyplomacja, Warszawa 2002, s. 223.

${ }^{18}$ L. Bazylow, Historia..., s. 368. 
bilizować sytuację wewnętrzną i przygotować się do nieuniknionej wojny z Turcją, która miała przynieść tak oczekiwane przez Imperium Rosyjskie zmiany w sytuacji międzynarodowej na Starym Kontynencie ${ }^{19}$.

Na przestrzeni dwóch dekad, oddzielających klęskę Imperium Rosyjskiego w wojnie krymskiej od kolejnych zmagań z Imperium Osmańskim o supremację i wpływy na Bałkanach i Zakaukaziu, nastąpiły wyraźne zmiany w sytuacji narodowościowej Bałkanów. Tendencja ta wynikała z rosnącej świadomości narodowej mieszkańców Półwyspu Bałkańskiego, korzystnych dla narodów bałkańskich zmian w procesach demograficznych, rosnącej niechęci do rządzących tymi obszarami Osmanów oraz wzrostu znaczenia kwestii narodowościowych w polityce europejskiej. W latach 60. XIX wieku odżyły na obszarze Starego Kontynentu przytłumione wcześniej klęską Wiosny Ludów kwestie narodowościowe. Imperium Rosyjskie, będące państwem wielonarodowym z dominującą pozycją narodu rosyjskiego, zmuszone było stawić czoła tendencjom decentralizacyjnym, separatystycznym. Sytuacja ustabilizowała się w latach 70. XX wieku, co pozwoliło na podjęcie próby rewizji warunków kongresu paryskiego z 1856 roku. W 1871 roku doszło do podpisania konwencji londyńskiej, w wyniku której Rosja otrzymała prawo swobodnej żeglugi po Morzu Czarnym, z wykorzystaniem cieśnin otwartych dla wszystkich statków handlowych. Wymagało to jednak zgody sułtana. Warunki konwencji londyńskiej nie satysfakcjonowały Rosjan, którzy dążyli do pełnego opanowania akwenu czarnomorskiego oraz przejęcia kontroli nad cieśninami ${ }^{20}$. W latach 1866-1869 na Krecie miał miejsce powstańczy zryw wymierzony w panowanie tureckie. Powstańców, których celem było zjednoczenie z Grecją w jednym organizmie państwowym, wspierała dyplomacja rosyjska, nie angażując jednak środków militarnych, bo na to Rosja była jeszcze zbyt słaba. Poza tym niechętne powstańcom okazały się państwa zachodnie, z Wielką Brytanią, Francją oraz Austro-Węgrami na czele ${ }^{21}$. Niemniej nie zahamowało to dynamicznie rozwijających się ruchów narodowościowych. W 1875 roku wybuchło powstanie w Bośni i Hercegowinie, wspierane przez rosyjski ruch panslawistyczny z Iwanem Aksakowem na czele. Powstańcom udawało się ze zmiennym szczęściem kontynuować walki aż do 1878 roku, kiedy ponownie jednym z teatrów rosyjsko-tureckich działań wojennych miały się okazać Bałkany ${ }^{22}$. Od połowy lat 70. XIX wieku dochodziło również do starć zbrojnych grup powstańczych przenikających z terytorium Rumunii oraz Serbii na obszar zamieszkiwany przez Bułgarów. Ci ostatni z coraz większą stanowczością wyrażali swoje dążenia niepodległościowe, w niezwykle krwawy sposób tłumione przez nieregularne oddziały tureckie Baszybuzuków ${ }^{23}$. W tej sytuacji wybuch konfliktu o zasięgu międzynarodowym był nieunikniony. W 1876 roku za namową władz rosyjskich Serbia i Czarnogóra wypo-

${ }^{19} \mathrm{~W}$ okresie poprzedzającym wybuch rosyjsko-tureckiego konfliktu zbrojnego 1877-1878 Rosjanie przeprowadzili szereg zmian w polityce wewnętrznej kraju, starając się umocnić przeżywające trudny okres imperium. W 1874 roku minister spraw wojskowych Dymitr Milutin przeprowadził reformę wojskową, mającą na celu wzmocnienie rosyjskich sił zbrojnych. W jej wyniku rosyjskie władze uzyskały prawo powoływania do armii wszystkich zdolnych do służby wojskowej Rosjan bez różnicy stanu. Skrócono za to okres odbywania służby wojskowej do 6 lat w wojskach lądowych oraz 7 lat w marynarce. O powołaniu w szeregi armii decydowało losowanie. Wyłączeni z niego byli jedyni żywiciele rodzin. B. B r o de c k i, Szypka i Plewna 1877, Bellona, 2010 , s. 18.

${ }^{20}$ M. Tan ty, Konflikty batkańskie w latach 1878-1918, Warszawa 1968, s. 17.

21 Ibidem, s. 19.

22 Ibidem, s. 19-20.

23 Ibidem, s. 21. 
wiedziały wojnę Turcji. Rosja wsparła państwa bałkańskie w walce z Imperium Osmańskim dostawami broni oraz ochotnikami. Gdy szala konfliktu zaczęła przechylać się na stronę turecką, na Kremlu podjęto decyzję o rozpoczęciu działań bojowych wymierzonych w Turcję ${ }^{24}$. W rosyjskiej polityce zagranicznej dały o sobie znać resentymenty panslawistyczne. $\mathrm{Z}$ powrotem zaczęto otwarcie głosić potrzebę powrotu do idei bizantynizmu. Nowemu rozdaniu w europejskiej polityce wobec Bałkanów sprzyjała również sytuacja międzynarodowa. Narastająca rywalizacja o kolonie pomiędzy Francją a Wielką Brytanią, porażka Austrii w wojnie z Prusami oraz zwycięstwo tych ostatnich w wojnie z Francją, co umożliwiło zjednoczenie Niemiec, przyczyniły się do osłabnięcia antyrosyjskiej koalicji, skutecznie dotąd uniemożliwiającej realizację rosyjskiej strategii wobec Bałkanów. Wszystkie te wydarzenia przyczyniły się z czasem do wzrostu antagonizmów politycznych między wielkimi europejskimi dworami, stanowiąc preludium do wojny powszechnej ${ }^{25}$.

\section{Wojna rosyjsko-turecka 1877/78. Znaczenie konfliktu dla Bałkanów}

Korzystając z zaskoczenia europejskiej opinii publicznej, w tym rządów wielkich mocarstw, Rosjanom udało się pokonać wojska tureckie. W wyniku prowadzonej kampanii wojennej armia rosyjska odniosła zwycięstwa w krwawych starciach pod Szypką i Plewną ${ }^{26}$. Rosyjskie wojska dotarły niemalże pod sam Konstantynopol (Stambuł), co zmusiło Imperium Osmańskie do zawarcia wielce niekorzystnego dla strony tureckiej pokoju w San Stefano w 1878 roku. W jego wyniku Bułgaria, Serbia, Czarnogóra oraz Rumunia miały uzyskać pełną suwerenność, kończąc tym samym ostatecznie okres obecności tureckiej na Bałkanach. Bośnia i Hercegowina miała być objęta głębokimi reformami aparatu władzy, zaś wpływy tureckie w tej części Bałkanów ograniczone do niezbędnego minimum. Rosja odzyskała utraconą na rzecz Mołdawii Południową Besarabię. Przy okazji Turcja poniosła również istotne straty terytorialne na rzecz Rosji na Zakaukaziu. Wynik wojny jednoznacznie wykazał słabość państwa tureckiego, które nie potrafiło skutecznie przeciwstawić się potędze rosyjskiej, a w dodatku coraz gorzej radziło sobie z tłumieniem kolejnych buntów narodów bałkańskich, wymierzonych w turecką obecność polityczną i wojskową. Wojna rosyjsko-turecka nie przeszła bez echa w Europie. Niemcy, Francja, Wielka Brytania oraz Austro-Węgry postanowiły zminimalizować straty polityczne i terytorialne poniesione w wyniku konfliktu przez stronę turecką, tym samym ograniczając rezultaty zwycięstwa odniesionego przez siły rosyjskie. W rezultacie na kongresie berlińskim w 1878 roku doszło do rewizji traktatu z San Stefano. Wielkie mocarstwa zgodziły się na utworzenie Bułgarii, ale w znacznie okrojonym terytorialnie kształcie, bez dostępu do Morza Egejskiego, oraz Macedonii. Bułgaria miała stać się lennem tureckim. Z południowej części Bułgarii wykrojono obszar Wschodniej Rumelii, która miała być autonomiczną częścią Imperium Osmańskiego, zgadzając się przy tym, aby zarówno w Bułgarii jak i Wschodniej Rumelii

${ }^{24}$ B. Je la vi c h, Historia..., s. 18-19; D. K oł o d z i j j z zy k, Turcja, Warszawa 2000, s. 24-26.

${ }_{25}$ T. A ron so n, Zwaśnieni monarchowie. Europejskie trony w przededniu katastrofy 1914 roku, Kraków 2014.

${ }^{26}$ B. B ro de c k i, Szypka i Plewna 1877...; I. R o st u n ow, Wojna rosyjsko-turecka 1877-1878, Warszawa 1982; A. Ko s eski, Wojna wyzwoleńcza 1877-1878, Warszawa 1978. 
stacjonował do czasu uspokojenia sytuacji rosyjski korpus wojskowy. Serbia i Czarnogóra musiały ustąpić z części zajętych w wojnie z Turcją obszarów, w zamian za co uznano jednak ich niepodległość. Stało się to również udziałem Rumunii. Bośnia i Hercegowina przeszły pod administrację Austro-Węgier, które wprowadziły na tę część Bałkanów własny korpus wojskowy. Turcja poniosła poważne straty, choć, co należy podkreślić, znacznie bardziej ograniczone, niż miało to miejsce w wyniku wcześniejszego porozumienia pokojowego z San Stefano. Imperium Osmańskiemu udało się utrzymać Wschodnie Bałkany, północne prowincje greckie, Albanię, Macedonię oraz Sandżak Nowopazarski. Austro-Węgry uzyskały prawo do okupacji Bośni i Hercegowiny, z zastrzeżeniem jednak formalnego zwierzchnictwa nad prowincją ze strony sułtana ${ }^{27}$.

Działania wojenne zakończone pokojem w San Stefano oraz późniejszymi ustaleniami kongresu berlińskiego wygenerowały poważne zmiany w polityce europejskiej:

Walkę wyzwoleńczą Słowian Bałkańskich śledziły z największą uwagą mocarstwa europejskie, które obawiały się, aby nie rozwinęła się ona niekorzystnie dla ich interesów,... zasadnicze sprzeczności zarysowały się pomiędzy Rosją, Anglią i Austro-Węgrami. Obawa przed groźbą przekształcenia konfliktów bałkańskich w wojnę europejską zmuszała je do szukania rozwiązań na drodze dyplomatycznej. Sprzeczności między nimi były jednak bardzo duże. Rosja pragnęła wzmocnienia swoich wpływów na Bałkanach oraz korzystnego rozwiązania sprawy cieśnin... Anglia i Austro-Węgry były wówczas głównymi przeciwnikami penetracji rosyjskiej na Bałkanach. Austro-Węgry dążyły do zagarnięcia Bośni i Hercegowiny, Anglia natomiast nie chciała dopuścić do umocnienia pozycji Rosji w cieśninach $\mathrm{i}$ do osłabienia Turcji, gdyż widziała w tym naruszenie swych interesów w krajach tureckich, na Bliskim Wschodzie i w Afryce ${ }^{28}$.

\section{Polityka Imperium Rosyjskiego wobec Bałkanów 1878-1914}

Kongres berliński przyniósł za sobą zmianę układu sił w Europie. Pogorszeniu uległy relacje rosyjsko-niemieckie, nie na tyle jednak, aby nie dokonać w 1881 roku restytucji porozumienia trzech cesarzy. W części dotyczącej Bałkanów układające się mocarstwa potwierdziły prawo Austro-Węgier do aneksji Bośni i Hercegowiny, gwarantowały również na zasadzie wzajemności neutralność, w razie gdyby jedna z układających się stron weszła w stan wojny z Francją, Wielką Brytanią lub Turcją. Układ ten przetrwał ledwie kilka lat. Niemcy oraz Austro-Węgry sprzeciwiały się rosyjskiej polityce wobec Bułgarii. Rosjanom udało się co prawda dokonać udanego przewrotu, w wyniku którego do władzy doszedł zwolennik porozumienia z Rosją, jednakże korzystna dla imperium Romanowów sytuacja uległa szybko odwróceniu w wyniku przejęcia władzy przez Ferdynanda Koburskiego. Od końca lat 80. XIX wieku zarówno w polityce bułgarskiej, jak również rumuńskiej przeważały wpływy niemieckie. Dopiero w 1896 roku nastąpiło wznowienie relacji dyplomatycznych pomiędzy Rosją a Bułgarią. Na wyraźniejsze jednak przesilenie we wzajemnych relacjach trzeba było czekać do 1911 roku, kiedy chcąc wykorzystać sytuację międzynarodową, książę Bułgarii, a zarazem gubernator Rumelii Wschodniej,

\footnotetext{
${ }^{27}$ L. B azy low, Historia..., s. 373-378; D. Kołodziej c zy k, Turcja, s. 26.

${ }^{28}$ M. Tanty, Konflikty..., s. 23.
} 
Ferdynand postanowił dokonać zmiany układu sił na Półwyspie Bałkańskim, do czego potrzebował przynajmniej akceptacji ze strony Imperium Rosyjskiego ${ }^{29}$. Kryzys wywołany klęską w wojnie z Japonią oraz późniejsza rewolucja, która przetoczyła się przez cały niemalże obszar państwa rosyjskiego, koncentrując się głównie na wielkich ośrodkach miejskich, przemysłowych, osłabiła zainteresowanie kwestią bałkańską. Stabilizacja, jaką przyniosły rządy Piotra Stołypina, zaowocowała jednak powrotem Rosji jako kluczowego gracza na obszarze Bałkanów. W 1912 roku rosyjskie władze doprowadziły do zawarcia bułgarsko-serbskiego sojuszu wymierzonego w Turcję. Nieco wbrew woli Rosji do układu dołączyły się Grecja oraz Czarnogóra ${ }^{30}$. Gdy w tureckich prowincjach - Albanii oraz Macedonii wybuchło skierowane przeciwko Osmanom powstanie, pomiędzy związkiem bałkańskim a Turcją doszło do konfliktu zbrojnego, który zakończył się dla strony tureckiej klęską, a do historii przeszedł jako I wojna bałkańska. Zbliżające się do kresu istnienia Imperium Osmańskie, ogarnięte wewnętrznym „młodotureckim” polityczno-społecznym wrzeniem, zmuszone było oddać państwom bałkańskim zajmowane do tej pory tereny, oprócz Albanii, Konstantynopola (Stambułu) oraz niewielkiego obszaru leżącego na zachód od miasta - Midi ${ }^{31}$. „Bałkańska beczka prochu”, jak nazywano ze względu na konfliktogenność obszar Bałkanów, nie dała jednak o sobie zapomnieć. Niedawni sojusznicy nie potrafili podzielić się zdobyczami terytorialnymi, formułując wobec siebie kolejne roszczenia. Największe niezadowolenie z wyników I wojny bałkańskiej wyrażała Bułgaria. W 1913 roku doszło do krótkiej, aczkolwiek intensywnej, kampanii wojskowej państw związku bałkańskiego wobec Bułgarii, która przyniosła w efekcie klęskę tej ostatniej. Państwo bułgarskie zmuszone zostało do ustępstw terytorialnych na rzecz sąsiadów. Przy okazji Turcja odzyskała Adrianopol, Rumunia Dobrudżę, Serbia wchłonęła Macedonię oraz wraz z Czarnogórą Sandżak Nowopazarski, Grecja zaś ziemie leżące w południowej Macedonii oraz część Epiru ze strategicznie ważnym miastem Janina ${ }^{32}$. II wojna bałkańska położyła definitywnie kres panowaniu Turcji na Bałkanach, której posiadanie ograniczyło się do Konstantynopola (Stambułu) oraz części Tracji, przyspieszyła również ostateczny upadek Imperium Osmańskiego. Nie rozwiązała natomiast sporów zarówno pomiędzy narodami bałkańskimi, jak również wielkimi mocarstwami uwikłanymi w wojny bałkańskie, które traktowały bałkańskie konflikty jako kolejne rozdanie kart w grze o strefy wpływów. Rosja tylko częściowo mogła być usatysfakcjonowana wynikami dwóch bałkańskich konfliktów. Wprawdzie wróciła po upokarzającej klęsce z Japonią i niepokojach wewnętrznych na arenę zmagań bałkańskich, ale podobnie jak miało to miejsce w przypadku innych uczestników gry o Bałkany, nie wyciągnęła wniosków z rosnącej emancypacji narodów bałkańskich. Te ostatnie w coraz większym stopniu chciały odgrywać samodzielną rolę w polityce międzynarodowej, niechętnie spoglądając na protekcyjne zabiegi ze strony wielkich mocarstw. Zarówno Rosji jak również Austro-Węgrom wydawało się, iż nadal trzymają klucz do rozwiązania konfliktu bałkańskiego, w pełni kontrolując sytuację. Tak jednak nie było. „Bałkański kocioł” wrzał nadal. Pre-

\footnotetext{
${ }^{29}$ L. B a zylow, Historia..., s. 378-379; M. Ta nty, Konflikty...., s. 34-43.

${ }^{30}$ R. R a b k a, Batkany 1912-1913, Warszawa 2010, s. 18-19; I. S t a w o w y-K a w k a, Historia Macedonii, Wrocław 2000, s. 164-167.

31 B. Jelavi c h, Historia..., s. 109-113.

32 Ibidem, s. 113- 114; zob. zmiany terytorialne i ludnościowe, do których doszło w wyniku I oraz II wojny bałkańskiej, G. Markow, Byłgarskoto kruszenie 1913, Sofia 1913, s. 225.
} 
tensje serbskie o dostęp do Adriatyku, który był blokowany zajętą przez Austro-Węgry Dalmacją, oraz spór o prawa ludności serbskiej w Bośni i Hercegowinie spowodowały, iż do wybuchu kolejnej wojny było blisko, zwłaszcza że żadne z wielkich mocarstw nie było usatysfakcjonowane podziałem strefy wpływów na kontynencie europejskim. Dnia 28 czerwca 1914 roku serbski nacjonalista Gawriło Princip zastrzelił arcyksięcia Ferdynanda, pretendenta do tronu cesarskiego w Wiedniu. Pomimo przyjęcia przez stronę serbską ultimatum, z wyjątkiem zgody na przeprowadzenie przez stronę austriacką śledztwa na terenie Serbii, doszło do wypowiedzenia stronie serbskiej wojny przez Austro-Węgry. Zapoczątkowało to cały łańcuch zdarzeń, który w rezultacie przyniósł wybuch I wojny światowej ${ }^{33}$.

\section{Zakończenie}

Słusznie zauważa w swojej Ilustrowanej historii świata J. M. Roberts, iż:

...potęgi europejskie unikały bezpośrednich konfrontacji, a w razie kryzysów używały ziem tureckich do zrekompensowania sobie wzajemnych ustępstw. W ten sposób rozebrano bałkańskie skrzydło gmachu imperium otomańskiego ${ }^{34}$.

Przez blisko sto lat, poczynając od końca lat 20. XIX wieku, a na pierwszej dekadzie XX wieku kończąc, udawało się ograniczyć konflikty bałkańskie, jak również wokół Bałkanów, do konfrontacji niewątpliwie ważnych, ale mających charakter peryferyjny, stanowiący tylko jeden z elementów kunsztownie wznoszonej od czasów kongresu wiedeńskiego 1814-1815 politycznej mozaiki. Pierwszym znaczącym wyłomem była wojna krymska, która zachwiała porządkiem europejskim. To ona zapoczątkowała na tyle mocne podziały, iż wyzwoliło to lawinę politycznych, militarnych zdarzeń, doprowadzając do wybuchu I wojny światowej. Iskra, która do niej doprowadziła, rozpaliła się na Bałkanach, regionie Europy, o który i wokół którego trwały spory wielkich mocarstw. Nie potrafiły one rozwiązać „,bałkańskiego węzła”, często zaś wykorzystywały państwa, narody bałkańskie do osiągnięcia własnych partykularnych celów politycznych. Wydawało się, że gra o Bałkany, rywalizacja wielkich mocarstw są prowadzone według pewnych reguł, przede wszystkim zaś, że pozostają pod kontrolą. Relatywnie krótkie starcia kończyły się pokojowymi układami, które tylko doraźnie rozwiązywały nabrzmiałe na Bałkanach konflikty, stanowiąc często preludium do nowych starć. Bałkany, stanowiące „miękkie podbrzusze” Imperium Rosyjskiego, choćby z powodu geopolitycznego położenia, ogniskowały uwagę dynastii Romanowów. Innym powodem były idee, które stały za rosyjską polityką w wieku XIX oraz pierwszych latach XX stulecia. Na plan pierwszy wysuwał się bizantynizm, kontynuujący wzniosłą myśl rzuconą w XV wieku przez mnicha Filoteusza z Pskowa o Rosji jako „Trzecim Rzymie”35. Istotną rolę odgrywał panslawizm - idea połączenia

${ }^{33}$ L. B a zy low, Historia..., s. 479-480; B. J e l a v i c h, Historia..., s. 121-129.

${ }^{34}$ Cyt. za J. M. R ob ert s, Ilustrowana historia świata. T. 3 - Wieki pary i atomu, Łódź 1991, s. 166.

35 J. P o tuls ki, Współczesne kierunki rosyjskiej myśli geopolitycznej. Między nauka, ideologicznym dyskursem a praktyka, Gdańsk 2010, s. 153-204; J. H. Billing to n, Ikona i topór. Historia kultury rosyjskiej, Kraków 2007, s. 53-54. 
wszystkich Słowian, zwłaszcza prawosławnych, pod berłem imperium carskiego. Upadek Imperium Osmańskiego przyniósł narodziny republiki tureckiej, która tym razem bez posługiwania się narzędziami militarnymi chciała wykorzystywać swoje wpływy na Bałkanach celem realizacji interesów politycznych i gospodarczych. Choć Rosja pozostała kluczowym graczem na bałkańskiej arenie, to nie udało się rosyjskim elitom politycznym osiągnąć strategicznie ważnych celów politycznych. Mrzonką okazała się idea panslawistyczna, bizantynizm zaś marzeniem nieosiągalnym dla słabnącego Imperium Rosyjskiego. Zaangażowanie w konflikty bałkańskie ze strony imperium Romanowów przyczyniło się w końcu do upadku carskiej Rosji i narodzin ZSRR. Konflikty bałkańskie w omawianym okresie 1826-1914 spowodowały nie tylko wzrost świadomości narodowej narodów bałkańskich, ale również nacjonalizm przechodzący w szowinizm. Od końca lat 70. XIX wieku to narody bałkańskie, wzorując się na swoim ciemiężcach, zaczęły przeprowadzać czystki etniczne, najpierw wśród ludności muzułmańskiej, w późniejszym okresie same między sobą ${ }^{36}$.

Mimo upływu wielu lat od zakończenia I, a potem II wojny światowej, Bałkany pozostają obszarem wzmożonego zainteresowania zarówno ze strony wielkich mocarstw, jak również Turcji, regionem o kruchej stabilności, targanym konfliktami narodowościowymi. Pewne sojusze, sympatie polityczne oraz zadawnione urazy pozostają jednak niezmienne. Wiele z państw uczestników gry o Bałkany musiało zweryfikować, zredefiniować na nowo swoją strategię wobec tego obszaru, uwzględniając zmieniającą się rzeczywistość polityczną ${ }^{37}$. Współczesna Rosja, podobnie jak miało to miejsce w przypadku imperium carskiego, motywowana historią, interesami narodowymi, ponownie chce odgrywać kluczową rolę na Bałkanach. Po okresie ,jelcynowskiej smuty” jej obecność w polityce bałkańskiej wydaje się umacniać.

\section{Bibliografia}

Aronson T., Zwaśnieni monarchowie. Europejskie trony w przededniu katastrofy 1914 roku, Kraków 2014.

Bazylow L., Historia Rosji, Warszawa 1983.

Bieniek K., Polityka zagraniczna Turcji wobec państw bałkańskich, Toruń 2010.

Billington J. H., Ikona i topór. Historia kultury rosyjskiej, Kraków 2007.

Brodecki B., Szypka i Plewna 1877, Bellona, Warszawa 2010.

Brzeziński A. M., Grecja, Warszawa 2002.

Chwastowa M., Smirnowa W. S., Skazkina S. D., Zorina W. A. (red.), Historia dyplomacji do 1871 roku, t. 1, Warszawa 1973.

Eberhardt P., Rosyjski panslawizm jako idea geopolityczna, http://jozefdarski.pl/uploads/zalacznik/7134/geopolitykanet-rosyjskipanslawizmjakoideageopolityczna.pdf (11.11.16)

Fiedorow N., Docz Bizantii [w:] Zamiatin D. N., Zamiatina A. N. (red.), Imperija prostranstwa: chrestomatija po geopolitike i geokul'ture, Moskwa 2003.

${ }^{36}$ D. Kołodziejczyk, Turcja, s. 62.

37 Słusznie więc zauważa Karol Bieniek, pisząc o roli dziedzictwa osmańskiego na Bałkanach, iż: „Przeszłość osmańska oznaczająca setki lat obecności Turcji na Bałkanach, musiała i w istocie wywarła silny wpływ na obie zaangażowane strony... wraz z upadkiem Imperium Osmańskiego i powstaniem Republiki Tureckiej wzajemne relacji nabrały innego wymiaru, a nowe i osłabione państwo tureckie musiało też zbudować nową sieć relacji z państwami, które niegdyś pozostawały pod jego panowaniem". Cyt. za K. Bienie k, Polityka zagraniczna Turcji wobec państw bałkańskich, Toruń 2008, s. 4. 
Graff T., Wizja polityczna Zbigniewa Oleśnickiego po śmierci Władysława III, Prace Komisji Środkowoeuropejskiej PAU, J. Machnik, I. Stawowy-Kawka (red.), t. XXII, Kraków 2014.

Heller M., Historia Imperium Rosyjskiego, Warszawa 2002.

Jelavich B., Historia Bałkanów. Wiek XX, Kraków 2005.

Kissinger H., Dyplomacja, Warszawa 2002.

Klimecki M., Krym 1854-1855, Warszawa 2006.

Kołodziejczyk D., Turcja, Warszawa 2000.

Konopczyński W., Polska a Turcja 1683-1792, Kraków-Warszawa 2013.

Koseski A., Wojna wyzwoleńcza 1877-1878, Warszawa 1978.

Kowalska H., Kultura bizantyjsko-prawosławna, [w:] Suchanek L. (red.), Rosjoznawstwo, Kraków 2004.

Liebfeld A., Napoleon III, Warszawa 1979.

Markow G., Byłgarskoto kruszenie 1913, Sofia 1913.

Montefiore S. S., Potiomkin. Książe książat, Warszawa 2000.

Podhorecki L., Wiedeń 1683, Warszawa 1983.

Potulski J., Współczesne kierunki rosyjskiej myśli geopolitycznej. Między nauka, ideologicznym dyskursem a praktyka, Gdańsk 2010.

Rabka R., Batkany 1912-1913, Warszawa 2010.

Reychman J., Historia Turcji, Wrocław-Warszawa-Kraków-Gdańsk 1973.

Roberts J. M., Ilustrowana historia świata. T. 3 - Wieki pary i atomu, Łódź 1991.

Rostunow I., Wojna rosyjsko-turecka 1877-1878, Warszawa 1982.

Stawowy-Kawka I., Historia Macedonii, Wrocław 2000.

Stefaniuk T., Danilewski panslawizm i wielość cywilizacji, Lublin 2006.

Tanty M., Konflikty bałkańskie w latach 1878-1918, Warszawa 1968.

Tarle J., Wojna krymska, t. 1-2, Warszawa 1953.

Wieczorkiewicz P., Historia wojen morskich. Wiek pary, Poznań 2015.

Willaume M. J., Batkany w XIX stuleciu, [w:] Podolak M., Wprowadzenie do studiów wschodnioeuropejskich. Bałkany: przeszłość, teraźniejszość, przyszłość, Lublin 2013.

Wolski J., Historia powszechna. Starożytność, Warszawa 1971.

Wróbel P., Krzyż i Półksiężyc. Zachodnie Bałkany wobec Turcji w latach 1444-1463, Warszawa 2012.

\section{Robert Kłaczyński}

\section{The Politics of the Russian Empire towards the Balkan states and nations 1830-1914}

\section{Summary}

The politics of Russian Empire towards Balkan states and nations 1830-1914, summarizes the most important problems of Russian political, military and economic expansion at the Balkan Peninsula in the mentioned period. The author attempts to define Russia's role in the nation and state creation processes in the Balkan Peninsula. The historical significance of Russia in ending Ottoman domination in Southern Europe is also underlined. Finally, the presentation focuses on the analogy between the politics of tsarist Russia towards the Balkans, and the politics of the contemporary Russian Federation towards this area.

Keywords: Russian Empire, Balkan states, Balkan nations, military expansion, economical expansion 